\title{
The Transportation Performance Analysis of Logistics for Perishable Foods in Greater Bandung
}

\author{
Hasriwan Putra ${ }^{1}$, Herma Juniati ${ }^{1}$, and Sukma Rahadian ${ }^{2}$ \\ ${ }^{1}$ Pusat Penelitian dan Pengembangan Transportasi Antarmoda, Kementerian Perhubungan, Indonesia \\ ${ }^{2}$ Politeknik Transportasi Darat Indonesia - STTD, Indonesia \\ e-mail: hasriwan15@gmail.com
}

\begin{abstract}
This article aims to analyze the transportation performance in logistics of perishable foods in Greater Bandung and to identify the product loss of mushrooms and cabbages. It can be concluded that the main factors influencing the performance of transportation for perishable foods are: (1) Transportation operating hours adjusted to harvest time and market opening time, (2) Trip routes divided by 2 are using the shortest/ closest route and using a toll road, (3) Type of vehicle depend on the scale of production, the scale of the order and the distance of the trip, (4) the sale of products from farmers according to the nearest market location. Transportation cost contributes about $2-5 \%$ of product price. And, main factor of transportation cost is load factor. For cabbage, there is a $\mathbf{2 0 \%}$ product loss from farmers to traders in central/ traditional markets.
\end{abstract}

Keywords-Transportation performance, Logistics, Perishable foods, Horticulture.

\section{INTRODUCTION}

$\mathrm{V}$ EGETABLES and fruit are the staples of the community with a ratio of 97.29 percent consuming vegetables and 3 out of 4 Indonesians consume fruits. West Java is one of the centers of horticulture product development. The focus of the development of the Department of Agriculture including orange, mangos teem, mango, pineapple, rambutan, onion, chili, potato, cabbage, mushrooms, chili, tomatoes and some other types. This article selects vegetables as the object of research, such as cabbage and mushrooms. Cabbage is the largest vegetable production in West Java Province and National [1]. While the mushrooms are popular product in Bandung Raya.

Some special characteristics of agricultural products including horticulture, namely [2]:

1. Seasonal: Agricultural products have seasonal properties both in the production system and consumption.

2. Safety, nutrition and health: Food products will have a direct impact on the body of someone who consumes. Therefore the safety factor, quality, traceability is an important issue.

3. Short product life and susceptible to damage: Biological properties of agricultural products result its life is short and vulnerable to damage caused by physical or physical stress chemistry.

4. Impact on the environment: Agricultural systems are at risk of the environment because it uses a lot of land, water and energy.

Clarify the logistics characteristics of agricultural products based on the actors in the supply chain, namely [3]:

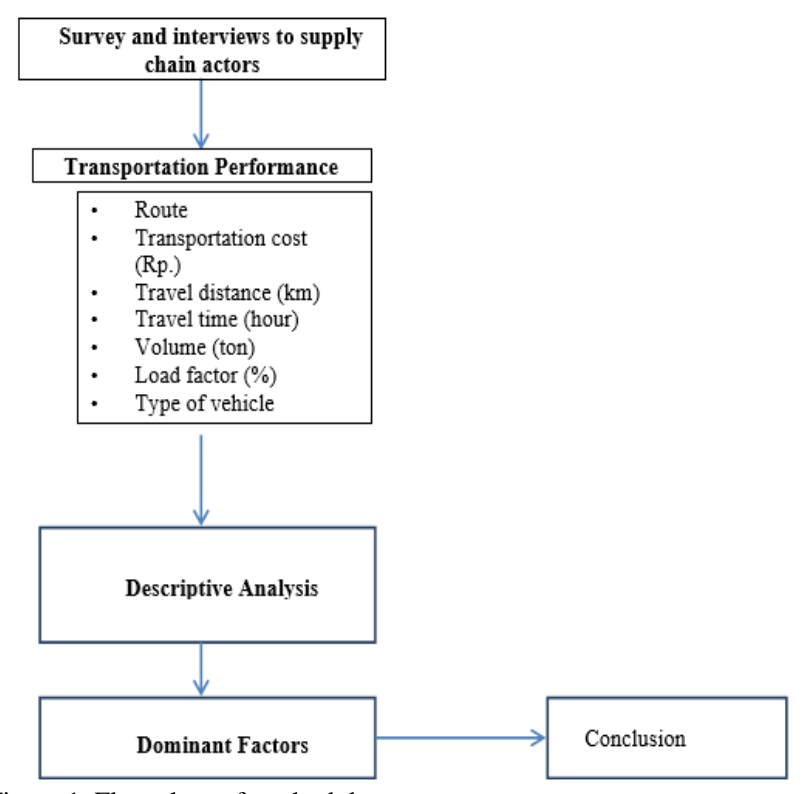

Figure 1. Flow chart of methodology.

1. Farmers

a. Long production period

b. Production is seasonal

c. The quality of yields and the volume supplied varies

2. Traders (dealer/ retailer)

a. Variation in quality and volume of supply from farmers

b. Supply is seasonal

c. Requires conditioning for transportation and storage space

3. Industry

a. Variables in the process greatly affect the quantity and quality of results due to the influence of varying biological properties, seasons, weather, pests, and other biological damage.

b. It takes time to wait for a quality test (quarantine)

c. Storage and buffer space must be special according to the nature of the raw material or product

d. Requires traceability in the production process given its importance quality and environmental factors.

Supply Chain Management (SCM) horticultural products will involve a series of activities of product supply, processing, supply and delivery to the customer. Customers want a supply quantity of vegetables according to plan requirements, a good level of quality and delivery schedule as planned. Fluctuations in demand and decrease in quality 


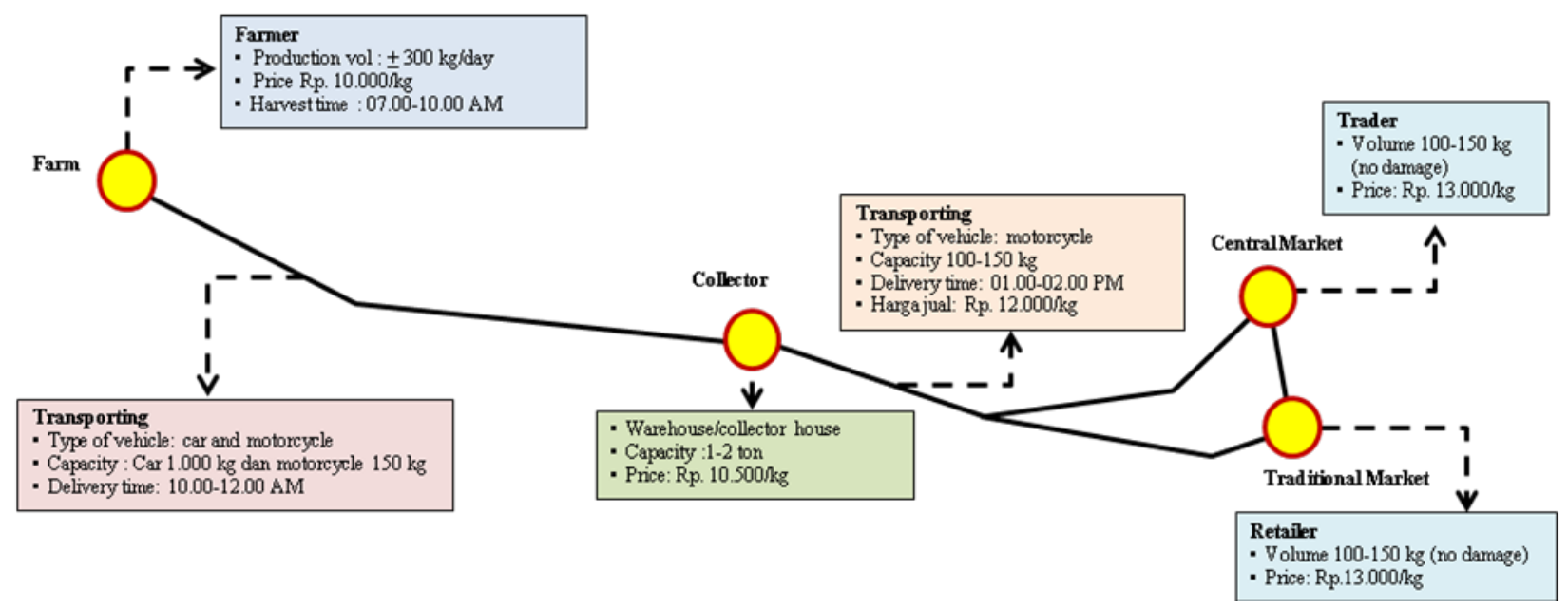

Figure 2. Mushroom Supply Chain Scheme.

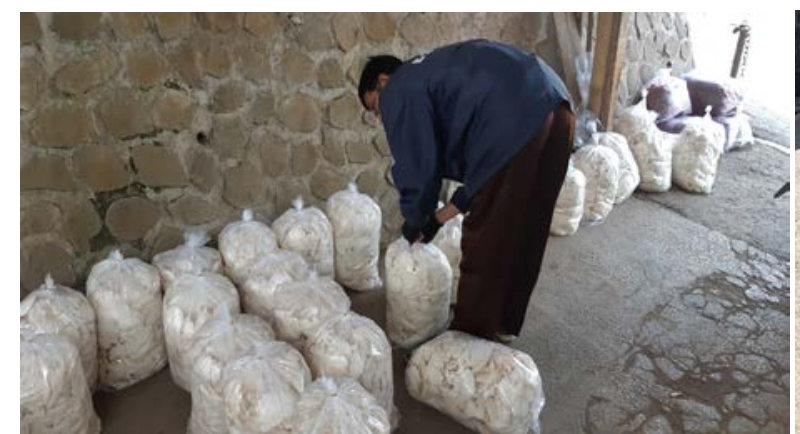

Figure 3. Mushroom collected and transported to market by motorcycle.

are all factors that need to be considered in the SCM horticultural products. SCM series are formed from the components of transportation, production, inventory and distribution is planned with attention to the key factors of customer satisfaction oriented. SCM operationally horticultural products need to be supported by a decisionmaking technique that accommodates the customer side and the supply of products.

Relationship between members of the SCM is done through the following stages:

1. Members SCM consist of horticultural products: suppliers, farmers, collector, food processing industry, agents, retailers and consumers.

2. The type of relationship between members can belong to several categories: essential (and often a strong relationship), temporary (sometimes associated with other members), non active (during active effect), no effect (not directly affected).

3. Agent, retailers and the end consumer is a member of the SCM system in the process of selling and consumption. [4]

Transportation high cost and minimal infrastructure conditions are inhibiting factors in increasing the competitiveness of Indonesian horticultural products [5]. Transportation high cost is caused by an inefficient supply chain system due to the large number of actors involved in the supply chain of agricultural products. Infrastructure conditions also affect to distribution costs, because broken infrastructure make many products being damaged when transported. Many number of products are damage when transported from the producer to the consumer, it will impact to logistics costs because many products cannot be sold. Therefore the logistics system for horticultural products

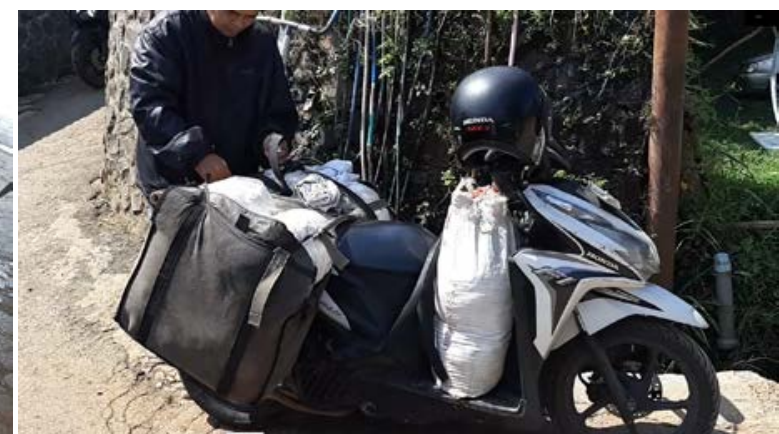

requires special handling and is different from manufactured products [6]. According to the Food and Agriculture Organization (FAO) [7], the product loss of perishable foods (fruits \& vegetables) is quite high at $15-50 \%$. In developing countries, product loss is estimated to occur in the postharvest process, namely in transporting. This research is proposed to review the transportation performance in logistics of perishable foods as following transportation cost, travel time and travel distance in Greater Bandung and to identify the product loss of mushrooms and cabbages.

\section{METHOD}

The study was conducted in July 2019 in Cisarua District, West Bandung Regency and Ciwidey District, Bandung District and Bandung City. The data used in this study are primary data and secondary data. Primary data obtained through observation and in depth interview to actors of supply chain namely farmers and farmer groups (Gapoktan), collectors/ dropper, and traders/retailers in traditional markets. The respondents interviewed were regulators consisting of the Agriculture and Food Crops Office of West Java Province and the West Java Provincial Industry and Trade Service Office. Secondary data were obtained from literature studies and agricultural statistical data from BPS, Ministry of Agriculture, Ministry of Trade and from other relevant sources.

\section{RESULT AND DISCUSSIONS}

\section{A. Supply Chain Analysis}




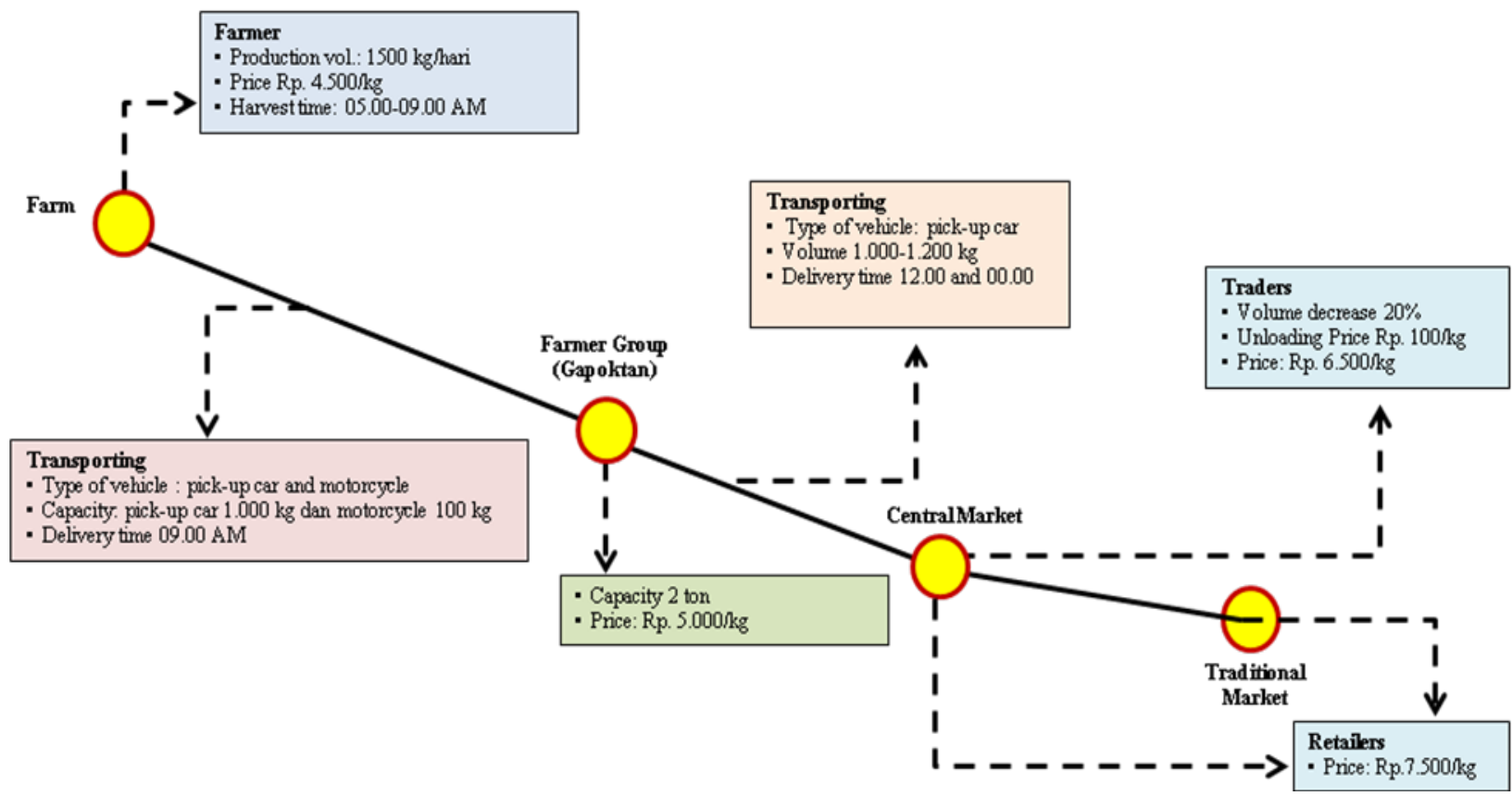

Figure 4. Cabbage Supply Chain Scheme.

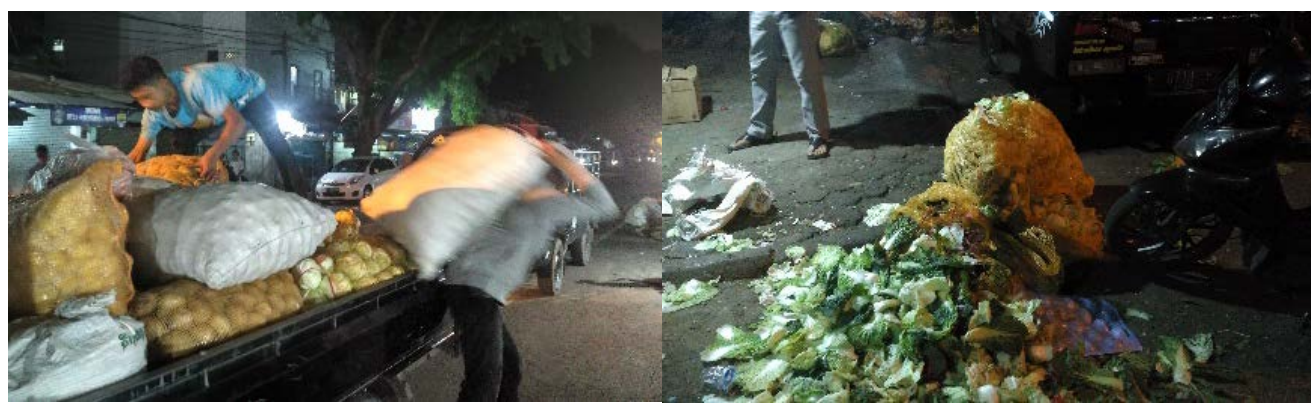

Figure 5. Process of unloading cabbages at market and broken cabbages.

Transport operating hours are adjusted to harvest time and market opening time. Mushrooms of Cisarua Lembang harvest at morning (06.00-10.00 AM), then they are sent to the Pasar Sederhana, Cihaurgeulis, Simpang Dago, Cicaheum at noon and stored in the market for sale tomorrow morning (market opening time at dawn). Mushrooms of Ciwidey harvest at morning (06.00-10.00 $\mathrm{AM}$ ), then they are sent to Ciroyom market, Soreang, Sayati at noon and stored in the market for sale tomorrow morning (market opening time at dawn) and sent to the Caringin market at noon (Caringin main market opening time from afternoon until tomorrow morning). Differences price of mushrooms from farmers to consumers are approximately Rp. 3,000/ kg (up 30\%). There was no reduction in the volume of transport of mushrooms at the market (shown on Figure 2).

Transporting vehicles from farmers to the Gapoktan warehouse are motorcycles (Figure 3), either 2 or 3 wheels and cars with a volume of 2.5 tones of pick up cars, 3 wheeler motorcycles is 0.5 tones and $100 \mathrm{~kg}$ motorbikes. Deliveries from farmers are carried out in the morning (06.00-10:00 AM). Delivery fleets to the market by using freight car (pick-up). Cabbage from Cibodas Lembang sent to Caringin market at noon (Caringin main market opening time starts in the afternoon until tomorrow morning), to the Simpang Dago and Cihaurgeulis markets in the early morning (when the Simpang Dago and Cihaurgeulis markets open at dawn / dawn). Cabbage from Gambung Ciwidey sent to Caringin market and Andir market during the daytime (opening time of Caringin and Andir markets starts from the afternoon until tomorrow morning), to Astana Anyar market and Sayati market at noon and stored in the market for sale tomorrow morning (market opening time at dawn), to Kordon and Kembar markets in the early morning (Kordon and Kembar markets open hours at dawn / dawn) (Figure 4).

The volume of cabbage has decreased approximately $20 \%$ when delivered to traders at central/ traditional market. It is about Rp. 1,375/kg (18.3\% of traders price) that disappear. Disparities of cabbages price from farmers to consumers are around Rp. 3,000/ kg (up 67\%) (Figure 5).

\section{B. Transportation Performance}

\section{1) Product Characteristics}

Mushroom of Cisarua Lembang characteristics are small production scale ( $<500 \mathrm{~kg} /$ day), small order scale and short travel distance $(<25 \mathrm{~km})$. In the meantime, mushroom of Ciwidey are large production scale $(500-1,000 \mathrm{~kg} /$ day), large order scale and long travel distance (> $25 \mathrm{~km})$. For cabbage in Cibodas and Ciwidey uniqueness are large production scale ( $>1,000 \mathrm{~kg} /$ day), large order scale and long travel distance $(>25 \mathrm{~km})$. (Table 1$)$

2) Coverage of sales area

Sales of products from farmers according to the closest market location. Sales of mushrooms from Cisarua are widely distributed to the western, northern and eastern Bandung market areas. Whereas the sale of mushrooms from 
The 8th International Conference on Transportation \& Logistics (T-LOG 2020)

Surabaya September 6th-7th 2020, Universitas Internasional Semen Indonesia (UISI), Gresik, Indonesia

Table 1.

Transportation performance from Farmers to Market

\begin{tabular}{|c|c|c|c|c|c|c|}
\hline No. & Type of vehicle & $\begin{array}{l}\text { Travel Distance } \\
(\mathrm{km})\end{array}$ & $\begin{array}{l}\text { Travel Time } \\
\text { (hours) }\end{array}$ & $\begin{array}{c}\text { Speed } \\
\text { (km/hours) }\end{array}$ & $\begin{array}{r}\text { Load } \\
\text { Factor }\end{array}$ & $\begin{array}{l}\text { Transport Cost } \\
\text { (Rp./kg) }\end{array}$ \\
\hline \multicolumn{7}{|c|}{ Mushroom of Lembang } \\
\hline 1 & Motorcycle & $16-24$ & $0.5-1$ & $17.5-37$ & 1.7 & $335-375$ \\
\hline \multicolumn{7}{|c|}{ Mushroom of Ciwidey } \\
\hline 2 & Freight car (pick-up) & $25-30$ & $0.65-1$ & $23-27$ & 1.02 & $289-346$ \\
\hline \multicolumn{7}{|c|}{ Cabbage Cibodas } \\
\hline & Freight car (pick-up) & $12-33$ & $0.48-1.35$ & $16-27$ & $1.02-1.23$ & $328-381$ \\
\hline \multicolumn{7}{|c|}{ Cabbage Gambung } \\
\hline 4 & Freight car (pick-up) & $24-36$ & $0.87-0.97$ & $28-40$ & 2 & $250-278$ \\
\hline
\end{tabular}

Ciwidey is distributed to the western and southern Bandung market areas. For cabbages sales from Cibodas are widely distributed in the northern Bandung market area. Meanwhile, the sale of cabbages from Gambung Ciwidey is distributed to the market areas of the western, southern and eastern of Bandung.

\section{3) Travel Routes}

The route for transporting mushrooms from Cisarua Lembang and cabbages from Cibodas Lembang use the nearest road and does not use a toll road. Meanwhile, Route for transporting mushrooms and cabbages from Ciwidey and Gambung use the Soreang-Pasirkoja toll road.

4) Types of vehicle

Type of vehicles from the farm to the warehouse use a motorcycle and freight car (pick up). And, type of vehicle from the warehouse to the market depends on the scale of production, the scale of the order and the distance of the trip. 5) Transport cost

It's range between 2 - 5\% of product price. The main factor influencing transport costs is the load factor. The higher the load factor 2 (200\%), then the lower the transport cost. However in safety point of view, it is not good enough because every vehicle has maximum payload that load factor must be maximum 1 (100\%).

\section{CONCLUSIONS}

The main factors that affect the transportation performance of logistics for perishable foods, as following : (1) Transport operating hours are adjusted to harvest time and market opening time (2) The trip route is divided into 2 such as by using the shortest/ nearest route and the toll road (3) Type of vehicle depends on the scale of production, the scale of the order and the distance of the trip. Motorcycle is used for small production scale $(<500 \mathrm{~kg} /$ day), small order scale and short travel distance $(<25 \mathrm{~km})$. Usage of freight car (pick-up) is for large production scale $(500-1,000 \mathrm{~kg} /$ day), large order scale and long travel distance $(>25 \mathrm{~km})$. Related to product loss, there is an approximately $20 \%$ loss of cabbages when delivered to traders in central/traditional market.

\section{ACKNOWLEDGEMENTS}

This research is funded by Intermodal Research and Development Center research programs. We wish to thank the Head of Intermodal Research and Development Center, the Agriculture and Food Crops Office of West Java Province, Industry and Trade Office of West Java Province who provided data, farmers group and market operator contacts.

\section{REFERENCES}

[1] Badan Pusat Statistik, "Konsumsi Buah dan Sayur Susenas Maret 2016," 2016.

[2] C. Mena and G. Stevens, "Delivering Performance in Food Supply Chain: an Introduction,” J. Mark., vol. 58, pp. 20-38, 2010.

[3] V. der J. Vorst, M. Beulens, and P. van Beek, "Innovation in Logistics and ICT,” Food Supply Chain Network, Innov. Agri-Food Syst., vol. 10, pp. 245-292, 2005.

[4] A. Harianja and Z. Hasibuan, "Sistem Informasi Supply Chain Management untuk Agribisnis Hortikultura di Indonesia,” in Seminar Nasional Himpunan Informatika Pertanian Indonesia 2009, 2009.

[5] R. Natawidjaya, T. Reardon, and S. Shetty, Horticultural Producers and Supermarket Development in Indonesia. Washington D.C., 2007.

[6] T. Fizzanty and Kusnandar, "Performance of Horticultural Supply Chain and Key SCM Principles,” in International Logistics Seminar and Workshop 2012 (ILSW 2012), 2012.

[7] FAO, "Post-harvest Losses in Perishable Crops," www.fao.org, 2019. [Online]. Available: http://www.fao.org/3/s8620e/S8620E06.htm\#II. Post-harvest losses in perishable crops. 